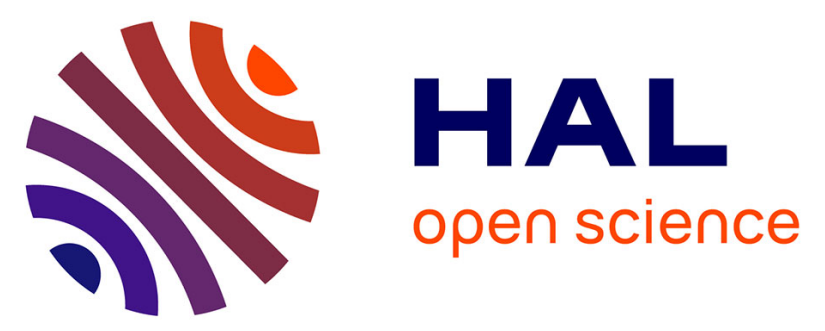

\title{
Relationship between environmental factors, dry matter loss and mycotoxin levels in stored wheat and maize infected with Fusarium species
}

\author{
Naresh Magan, Kalliopi Mylona, Michael Sulyok
}

\section{- To cite this version:}

Naresh Magan, Kalliopi Mylona, Michael Sulyok. Relationship between environmental factors, dry matter loss and mycotoxin levels in stored wheat and maize infected with Fusarium species. Food Additives and Contaminants, 2012, pp.1. 10.1080/19440049.2012.672340 . hal-00811704

\author{
HAL Id: hal-00811704 \\ https://hal.science/hal-00811704
}

Submitted on 11 Apr 2013

HAL is a multi-disciplinary open access archive for the deposit and dissemination of scientific research documents, whether they are published or not. The documents may come from teaching and research institutions in France or abroad, or from public or private research centers.
L'archive ouverte pluridisciplinaire $\mathbf{H A L}$, est destinée au dépôt et à la diffusion de documents scientifiques de niveau recherche, publiés ou non, émanant des établissements d'enseignement et de recherche français ou étrangers, des laboratoires publics ou privés. 


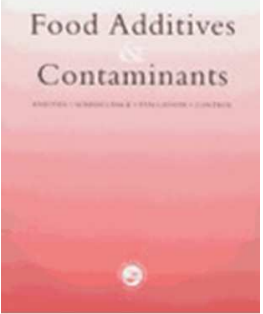

\section{Relationship between environmental factors, dry matter loss and mycotoxin levels in stored wheat and maize infected with Fusarium species}

\begin{tabular}{|c|c|}
\hline Journal: & Food Additives and Contaminants \\
\hline Manuscript ID: & TFAC-2012-037.R1 \\
\hline Manuscript Type: & Original Research Paper \\
\hline Date Submitted by the Author: & 29-Feb-2012 \\
\hline Complete List of Authors: & $\begin{array}{l}\text { Magan, Naresh; Cranfield University, Applied Mycology } \\
\text { Mylona, Kalliopi; Cranfield University, Applied Mycology Group } \\
\text { Sulyok, Michael; University of Natural Resources and Life Sciences, Vienna, } \\
\text { Department of Agrobiotechnology (IFA-Tulln) }\end{array}$ \\
\hline Methods/Techniques: & Mycology, LC/MS \\
\hline Additives/Contaminants: & $\begin{array}{l}\text { Mycotoxins, Mycotoxins - fumonisins, Mycotoxins - fusarium, Mycotoxins - } \\
\text { trichothecenes }\end{array}$ \\
\hline Food Types: & Cereals and grain, Cereals \\
\hline Abstract: & $\begin{array}{l}\text { This study examined the relationship between storage environmental } \\
\text { factors (water activity (aw) }(0.89-0.97) \text { and temperature }\left(15-30^{\circ} \mathrm{C}\right) \text { ), } \\
\text { colonisation of wheat and maize by Fusarium graminearum and F. } \\
\text { verticillioides respectively and the dry matter losses (DMLs) caused, and } \\
\text { quantified the contamination with deoxynivalenol (DON), zearalenone } \\
\text { (ZEA) and fumonisins (FUMs) during storage. Fungal growth was assessed } \\
\text { by the amount of CO2 produced under different interacting conditions of } \\
\text { aw and temperature. DMLs were quantified using the cumulative CO2 data } \\
\text { and these were shown to increase as temperature and aw increased. The } \\
\text { amount of DON, ZEA (wheat for human consumption) and FUMs (feed } \\
\text { maize) produced was significantly affected by the storage conditions. The } \\
\text { three toxins however showed different patterns of production. Optimum for } \\
\text { DON was at the wettest conditions ( } 0.97 \text { aw) and the highest temperature } \\
\left.\text { assessed ( } 30^{\circ} \mathrm{C}\right) \text {, while for ZEA this shifted to } 25^{\circ} \mathrm{C} \text {. FUMs were produced } \\
\text { in higher amounts in maize at } 30^{\circ} \mathrm{C} \text { and } 0.97 \text { aw, however, at intermediate } \\
\text { aw levels }\left(0.955 \text { aw) the highest production occurred at } 25^{\circ} \mathrm{C} \text { followed by }\right. \\
20^{\circ} \mathrm{C} \text {. Polynomial models were developed for the effect of the storage } \\
\text { factors on DMLs and toxin production. DMLs under different environmental } \\
\text { conditions were significantly correlated with DON and FUMs. DON } \\
\text { contamination was above the EU limits in at least } 80 \% \text { of the wheat }\end{array}$ \\
\hline
\end{tabular}


2

3

4

5

6

7

8

9

10

samples with DMLs $>1 \%$, while at least $70 \%$ of the same samples contained ZEA above the respective EU legislative limits. Similarly, at least $75 \%$ of the maize samples with DMLs $\geq 0.9 \%$ exceeded the EU limits for the sum of fumonisins in feed. These results show that it may be possible to use temporal $\mathrm{CO} 2$ production during storage of grains as an indicator of the level of contamination of the grain with mycotoxins.

\section{SCHOLARONE ${ }^{\text {m }}$}

Manuscripts 
1 Relationship between environmental factors, dry matter loss and mycotoxin

2 levels in stored wheat and maize infected with Fusarium species

3

$4 \quad$ Kalliopi Mylona ${ }^{a}$, Michael Sulyok $^{b}$ and Naresh Magan ${ }^{a^{*}}$

5

$6 \quad{ }^{a}$ Applied Mycology Group, Cranfield Health, Cranfield University, Bedford MK43 OAL, 7 UK; ${ }^{b}$ Department of Agrobiotechnology, University of Natural Resources and Life

8 Sciences, IFA-Tulln, Austria

9

$10 *$ Corresponding author: Prof Naresh Magan, Applied Mycology Group, Cranfield

11 Health, Cranfield University, Bedford MK43 OAL, UK.

12 E.mail: n.magan@cranfield.ac.uk

13

14 Running title: Dry matter losses and mycotoxins in wheat and maize 
15 This study examined the relationship between storage environmental factors (water 16 activity $\left(\mathrm{a}_{\mathrm{w}}\right)(0.89-0.97)$ and temperature $\left.\left(15-30^{\circ} \mathrm{C}\right)\right)$, colonisation of wheat and maize 17 by Fusarium graminearum and $F$. verticillioides respectively and the dry matter 18 losses (DMLs) caused, and quantified the contamination with deoxynivalenol (DON), 19 zearalenone (ZEA) and fumonisins (FUMs) during storage. Fungal growth was 20 assessed by the amount of $\mathrm{CO}_{2}$ produced under different interacting conditions of $\mathrm{a}_{\mathrm{w}}$ 21 and temperature. DMLs were quantified using the cumulative $\mathrm{CO}_{2}$ data and these 22 were shown to increase as temperature and $a_{w}$ increased. The amount of DON, ZEA 23 (wheat for human consumption) and FUMs (feed maize) produced was significantly 24 affected by the storage conditions. The three toxins however showed different 25 patterns of production. Optimum for DON was at the wettest conditions $\left(0.97 \mathrm{a}_{\mathrm{w}}\right)$ and 26 the highest temperature assessed $\left(30^{\circ} \mathrm{C}\right)$, while for ZEA this shifted to $25^{\circ} \mathrm{C}$. FUMs 27 were produced in higher amounts in maize at $30^{\circ} \mathrm{C}$ and $0.97 \mathrm{a}_{\mathrm{w}}$, however, at 28 intermediate $\mathrm{a}_{\mathrm{w}}$ levels $\left(0.955 \mathrm{a}_{\mathrm{w}}\right)$ the highest production occurred at $25^{\circ} \mathrm{C}$ followed by $2920^{\circ} \mathrm{C}$. Polynomial models were developed for the effect of the storage factors on 30 DMLs and toxin production. DMLs under different environmental conditions were 31 significantly correlated with DON and FUMs. DON contamination was above the EU 32 limits in at least $80 \%$ of the wheat samples with DMLs $>1 \%$, while at least $70 \%$ of the 33 same samples contained ZEA above the respective EU legislative limits. Similarly, at 34 least $75 \%$ of the maize samples with DMLs $\geq 0.9 \%$ exceeded the EU limits for the 35 sum of fumonisins in feed. These results show that it may be possible to use 36 temporal $\mathrm{CO}_{2}$ production during storage of grains as an indicator of the level of 37 contamination of the grain with mycotoxins. 
38 Keywords: Respiration, dry matter loss, Fusarium graminearum, F. verticillioides, water activity, temperature, grain storage, deoxynivalenol, zearalenone, fumonisins, mycotoxins, EU legislative limits

\section{Introduction}

Wheat, maize and rice are the most important staple foods world-wide (FAO, 2009). They represent the key food chains and are the major nutritional components for both food and feed. Thus any deterioration in the quality of these commodities due to fungal spoilage or contamination with mycotoxins results in a significant 47 impact on consumer and animal health.

Wheat and maize are commonly colonised by Fusarium species from the field.

49 Poor drying during the harvesting phase or storage of damp grain can facilitate rapid 50 colonisation by spoilage and mycotoxigenic moulds at the post-harvest stage 51 (Magan and Aldred, 2007; Magan et al., 2010). This results in quality, dry matter and 52 nutritional losses with significant economic consequences. Colonisation by Fusarium 53 species can also result in contamination with mycotoxins. Thus, F. graminearum can 54 contaminate wheat with deoxynivalenol(DON), nivalenol and zearalenone (ZEA), 55 while F. verticillioides can contaminate maize with fumonisins (FUMs). In recent 56 years type $A$ trichothecenes (T-2 andHT-2 toxins) produced by $F$. langsethiae and $F$. 57 sporotrichioides have also become of concern especially in oats and barley, but also 58 in wheat. Contamination of these grains with fusarium toxins has generally been 59 considered as more significant at the pre-harvest stage (Cleveland et al, 2003; Miller, 60 2008). However, several studies have demonstrated that fusarium toxins may also 61 proliferate during storage when damp conditions occur (Wagacha and Muthomi, 
62 2008), during harvesting and due to poor management of the drying phase.

63 Therefore effective management of storage conditions is essential for conservation 64 of both grain quality and safety post-harvest.

65 Due to the toxic effects of fusarium toxins on animals and humans, many 66 countries world-wide have established legislative limits for these compounds in food 67 and feed. In Europe these limits are harmonised (European Commission (EC), 68 2006a) and methods for the sampling and analysis of these toxins in different 69 products are also established (EC, 2006b). Finally, inspection and control measures 70 enforce these limits in products produced within Europe and check the compliance of 71 imported products from third countries.

However, despite the stringent control measures in place, contaminated products are still identified in Europe. Since 2005 between 650 and 1000 notifications for mycotoxins in food and feed are received each year by the Rapid 75 Alert System for Food and Feed (RASFF), the vast majority of which concerns aflatoxins. Notifications concerning fusarium toxins have usually been <20per year mostly for FUMs, but also DON and ZEA in cereals, cereal products or feed (EC, 2005-2009). Fusarium toxins are very stable molecules and once formed, traditional food and feed processing techniques are inefficient in removing them from the 80 products. It is therefore important to investigate further the conditions conducive to 81 contamination by Fusarium species in order to be able to efficiently predict and 82 prevent toxin accumulation in grain.

There have been many attempts to develop "storability risk indexes" for quality 84 losses during storage. These were reviewed by Fleurat-Lessard (2002) and include 85 the time to the appearance of microscopic or visible mould, ergosterol measurement, 
86 the analysis of volatiles associated with fungal growth and quantitative enzyme 87 production. Recently, a similar approach, based on time to visible moulding, has 88 been used to develop safe storage guidelines for durum wheat although the accuracy of this approach needs to be debated (Nithya et al., 2011).Dry matter losses (DMLs) have also been considered as a quality indicator and values as low as 0.04\% DML has been reported in relation to seed germination and visible moulding 92 in wheat (White et al., 1982a, b; Lacey et al., 1994). Seitz et al. (1982) indicated that $93 \quad 0.5 \%$ DML would be enough to downgrade maize from food to feed quality with an increased risk of aflatoxin contamination depending on the initial spore load at the time of storage. However, not much information is available on the risk of fumonisin contamination of maize.

In terms of predicting toxin contamination in stored grain, Lund and Frisvad (2003) and Lindblad et al. (2004) related colony forming units (CFUs) of Penicillium verrucosum to the storage conditions and the probability of exceeding the EU legislative limits for ochratoxin A. Yong and Cousin (2001) obtained some good correlations comparing Aspergillus parasiticus colony counts to enzyme-linked immunosorbent assay (ELISA) quantification and ergosterol measurements in order to detect aflatoxin contamination in maize and peanut samples. More recently Pasquali et al. (2010) related the counts of a nivalenol chemotype Fusarium culmorum strain to the mycotoxin content of grain, while Casado et al. (2010) found no correlation between the number of infected kernels and fumonisin contamination of a maize bulk. However, no studies have attempted to quantitatively relate DMLs to 108 toxin contamination during storage and use these losses as a safety risk index. Such 109 information would be very valuable in assessing the potential for exceeding the legislative limits for DON and ZEA in wheat or for FUMs in maize. 
111 The objectives of this study were to (a) quantify the DMLs caused during $F$. 112 graminearum and F. verticillioides colonisation of wheat for human consumption and 113 feed maize respectively based on the amounts of $\mathrm{CO}_{2}$ produced under different 114 combinations of $\mathrm{a}_{\mathrm{w}} \mathrm{x}$ temperature interactions, (b) quantify the production of DON 115 and ZEA in wheat and FUMs in maize under the same conditions and (c) develop 116 models to relate DMLs to mycotoxin contamination taking into account $a_{w} x$ 117 temperature effects and identify the threshold DMLs which would result in exceeding 118 the EU legislative limits.

\section{Materials and methods}

\section{Fungal cultures}

The F. graminearum strain (isolate L1-2/2D) was supplied by the University of 123 Lleida, Catalonia, Spain; it was isolated from wheat and is a known high producer of 124 deoxynivalenol (DON) and zearalenone (ZEA) (Marín et al., 2010). The $F$. 125 verticillioides strain (MPVP 294) originated from maize in Italy and is a known high 126 producer of fumonisins $B_{1}$ and $B_{2}$ (Etcheverry et al., 2009). This strain was supplied 127 by Università Cattolica del Sacro Cuore (UCSC), Piacenza, Italy. The cultures were 128 maintained on Malt Extract Agar (MEA) media (OXOID, malt extract, 30; mycological 129 peptone, 5; agar, $15 \mathrm{~g} / \mathrm{l})$.

Grain treatment and water activity adjustment of wheat and maize

133 while feed maize was supplied by UCSC, Piacenza, Italy. Both cereals (2008/2009

Wheat used in this experiment was obtained from a local Bedfordshire farm 
134 harvest year) were treated with 12 kGy gamma irradiation (Isotron, Plc, Swindon,

135 UK) and stored at $4^{\circ} \mathrm{C}$. At this irradiation dose the cereals retained germinative 136 capacity but were free of fungal contamination (Hope et al., 2005).

137 Water adsorption curves were prepared for both grains as previously described 138 (Mylona and Magan, 2011).Although the water adsorption curves were relatively 139 stable over the first three days of measurement, the data of the $3^{\text {rd }}$ day were used for 140 the determination of the amount of water required to achieve the target $a_{w}$ levels. 141 Irradiated grain was modified to the treatment $a_{w}$ levels by the addition of sterile 142 distilled water and the treatments used for wheat were: $0.89,0.94$ and $0.97 \mathrm{a}_{\mathrm{w}}$ and 143 for maize:0.91, 0.955 and $0.97 a_{w}$ which equated to $20.5,26$ and $32 \%$ and 19,25 and $14427.5 \%$ moisture content (wet weight basis) respectively. These $a_{w}$ levels were 145 selected to simulate ambient drying of moist grain or poor storage management 146 practices that may occur when moist grain is mixed with drier grain. These $a_{w}$ levels 147 are representative of marginal and optimum conditions for the growth of the relevant 148 fungal species in these cereal types (Sanchis and Magan, 2004).

150 Grain inoculation and storage

151 Wheat and maize treatments were inoculated with $1 \mathrm{ml}$ of spore suspension and 152 thoroughly mixed. Spore suspensions were obtained from 10 day old cultures of $F$. 153 graminearum and F. verticillioides flooded with Tween 80 solution (one drop of 154 Tween 80 (ACROS organics) in 100ml of sterile water) and gently scraping the 155 culture surface with a sterile spatula. The concentration of the spores was 156 determined using a haemocytometer (Olympus BX40 microscope, Microoptical Co.; 157 slide Marienfeld superior, Germany) and adjusted by dilution to $10^{4}$ spores $\mathrm{ml}^{-1}$. 
158 Three replicates of $10 \mathrm{~g}$ (wet weight) were placed in $40 \mathrm{ml}$ vials (Chromacol Ltd, 159 UK) and incubated in $10 \mathrm{~L}$ closed containers in which the target equilibrium relative 160 humidity was maintained using 0.5 l of an appropriate glycerol/water solution. The 161 samples were stored at four temperatures $\left(15,20,25\right.$ and $\left.30{ }^{\circ} \mathrm{C}\right)$ for 10 days.

\section{Respiration measurement by Gas Chromatography (GC)}

Treatment samples were sealed daily for one hour with injection caps to allow for

$\mathrm{CO}_{2}$ accumulation in the headspace. $5 \mathrm{ml}$ of the headspace were withdrawn by a

syringe and directly inserted in the Gas Chromatograph (GC) for $\mathrm{CO}_{2}$ analysis. The

167 GC used was a GC 8000 Series, Carlo Erba Instruments with a Hot Wire Detector 168 (HWD) and Helium as a carrier gas. For the $\mathrm{CO}_{2}$ analysis a column packed with 169 Porapak Q was used. Chromatograms were obtained by a DP 800 Data Processor, 170 Carlo Erba (Mylona and Magan, 2011).

The respiration rate and the total DMLs were calculated for each sample from the percentage $\mathrm{CO}_{2}$ concentration data obtained, as previously described (Mylona and Magan, 2011). DMLs were adjusted as per initial dry weight of treatments. At the end of the 10-day incubation period the samples were frozen at $-40^{\circ} \mathrm{C}$ for subsequent toxin analysis.

\section{Toxin extraction/analysis}

177 The samples were oven-dried at $60^{\circ} \mathrm{C}$ for 24 hours and then milled in a small 178 laboratory blender (Waring Commercial, Christison, UK). Samples were analysed for 179 fusarium toxins by Liquid Chromatography-Tandem Mass Spectrometry (LC-MS/MS) 180 (Sulyok et al., 2006; Vishwanath et al., 2009). Quantitation was based on external 
181 calibration using certified liquid standards, no isotopically-labelled internal standards

182 were used. Results were corrected for apparent recovery that was $82 \%$ in case of 183 zearalenone as determined by analysis of the untreated wheat sample after spiking.

184 The same approach was not applicable for DON and the fumonisins, as the 185 untreated samples were already contaminated. Therefore, the apparent recovery 186 obtained during method validation (57\% for $\mathrm{FB}_{1}, 70 \%$ for $\mathrm{FB}_{2}, 95 \%$ for $\mathrm{DON}$; Sulyok 187 et al. 2006) was used to correct the results. The accuracy of the method was 188 externally checked by participation in proficiency testing organized by BIPEA 189 (Bureau Inter Professionel d’Etudes Analytiques; Gennevilliers, France). Z-scores 190 were 0.4 and 0.62 for DON in two wheat samples, -0.8 and -1.09 for ZON in two 191 wheat samples and 1.36 and 1.55 for $\mathrm{FB}_{1}$ and $\mathrm{FB}_{2}$, respectively in a sample of 192 maize.

\section{Statistical analysis and modelling of the results}

Statistical analysis of DML and toxin analysis data

200 Total DML data and toxin analysis data were assessed by the Shapiro-Wilk, W 201 test for normality. Data not normally distributed were logarithmically transformed in 202 order to stabilise the variance and their normality reassessed by the Shapiro-Wilk W 203 test. Normally distributed log-transformed data were analysed by one and two-way 
204 ANOVA for determination of the significance of the effect of each factor and their 205 interaction on the variable. Log-transformed data still not normally distributed were 206 analysed by the Kruskal-Wallis test by ranks.

207 Model development

208 Forward stepwise regression (STATISTICA 9) and Regression (Microsoft Office 209 Excel 2007) were used to obtain polynomial equations for DML and toxin production 210 with regard to the storage conditions ( $\mathrm{a}_{\mathrm{w}}$ and temperature). The assumptions of 211 linearity and normally distributed residuals were assessed, producing normal plots of 212 the residuals. Where residuals were not normally distributed the variable was 213 logarithmically transformed and the normality reassessed. Contour maps were also 214 constructed (Microsoft Office Excel 2007) to indicate the effects of storage conditions 215 on DMLs and toxin production for both wheat and maize.

216 Correlations between DMLs and toxin production data

217 DMLs were plotted against toxin production for DON, ZEA (wheat) and FUMs 218 (maize). The Spearman Rank Order Correlations test was used to determine the 219 significance of the correlation between the two variables in each case.

\section{Results}

222 Respiration rates and $\mathrm{CO}_{2}$ production by $F$. graminearum in wheat and $F$. 223 verticillioides in maize as affected by the storage conditions 
225 Overall, respiration in wheat at $0.89 \mathrm{a}_{\mathrm{w}}$ and $15^{\circ} \mathrm{C}$ was constantly very low 226 throughout the 10 day storage period (data not shown). This can be attributed to the 227 grain, since no fungal growth was observed at these conditions. Respiration rates 228 generally started increasing after 2-4 days incubation and this was due to the 229 initiation of fungal growth (data not shown). Respiration data obtained until that point 230 in time were attributed to the respiration of the grain and they were generally stable 231 under a set combination of storage conditions, but higher with increasing $a_{w}$ and 232 temperature. Once fungal growth was initiated, respiration rates started increasing 233 with time and the increase was generally higher under a set combination of storage 234 conditions. Thus the fungal contribution to the total respiration was increasingly more 235 significant representing $>75 \%$ of the total respiration in the wheat experiment by the $23610^{\text {th }}$ day of incubation under the most favourable storage conditions. Similar 237 observations were also made in the maize experiment, however in this case 238 respiration rates started increasing from the second day in the most favourable 239 combinations of storage conditions $\left(T \geq 20^{\circ} \mathrm{C}, \mathrm{a}_{\mathrm{w}} \geq 0.955\right)$. In maize under the most 240 favourable conditions tested $>85 \%$ of the respiration measured on the $10^{\text {th }}$ day of 241 storage was due to fungal colonisation. The respiration of the grain under each 242 combination of storage conditions has not been subtracted from the total respiration 243 measured, as this is considered unrealistic, since in practice these two could not be 244 dissociated, i.e. during $\mathrm{CO}_{2}$ monitoring in silos.

245 Figure 1 shows the effects of $\mathrm{a}_{\mathrm{w}}$ and temperature on the cumulative $\mathrm{CO}_{2}$ 246 production during wheat colonisation by $F$. graminearum. This was very low at $2470.89 a_{w}$, but generally increased with increasing $a_{w}$ and temperature over time and 248 the maximum was observed under the wettest conditions and $30^{\circ} \mathrm{C}$ where the total 249 accumulated $\mathrm{CO}_{2}$ production was also the highest. 
250 A similar trend in the respiration rates and total $\mathrm{CO}_{2}$ production with increasing $251 a_{w}$ and temperature over time was observed during $F$. verticillioides colonisation of 252 maize. Overall, the cumulative $\mathrm{CO}_{2}$ production during the respiration of $F$. 253 verticillioides on maize was higher than that of $F$. graminearum on wheat.

254

\section{Effect of water activity and temperature on dry matter losses in wheat and} maize during storage

Dry matter losses (DMLs) in wheat and maize during colonisation by $F$. graminearum and $F$. verticillioides respectively increased with increasing $a_{w}$ and temperature. The maximum was observed under the wettest conditions and highest temperature assessed. Overall, DMLs were higher in maize than in wheat, which paralleled the higher respiration rates observed in these studies. Figure 2 shows the DMLs caused in (a) wheat and (b) maize after 10 days colonisation by $F$. graminearum and $F$. verticillioides respectively, under different combinations of storage conditions. The maximum standard errors $\left(\mathrm{SE}_{\max }\right)$ in the determination of DMLs in each experiment have been calculated and are included in the legend of Figure 2. As temperature and $a_{w}$ increased the relative DMLs also increased. At $30^{\circ} \mathrm{C}$ DMLs were highest and were about 7 and $15 \%$ respectively.

Statistically, the effect of $a_{w}$ on logDMLs in wheat (normally distributed: W, $p=0.090)$ was highly significant $(p=0,000)$, while the effect of temperature was significant $(p=0.043)$. The interaction of the two factors $\left(a_{w} \times T\right)$ on logDMLs was also highly significant $(p=0,000)$.For maize, logDML data were also normally distributed $(W, p=0.498)$ and in this case the effects of both $a_{w}(p=0.000)$ and temperature $(p=0.000)$ were highly significant, as well as their interaction $\left(a_{w} \times T\right)(p=0.006)$. 
275

276

277

278

279

280

281

282

283

284

285

286

287

288

289

290

291

292

293

294

295

296

297

\section{Mycotoxin production in wheat and maize under different storage conditions}

Figure 3 shows the pattern of (a) DON and (b) ZEA production in wheat by $F$. graminearum and (c) fumonisins production by $F$. verticillioides in maize under different combinations of $\mathrm{a}_{\mathrm{w}}$ and temperature. The maximum standard errors (SE $\left.\mathrm{max}_{\max }\right)$ in the determination of each toxin have also been calculated and are included in the legend of Figure 3. DON and ZEA levels were low at all temperatures and $0.89 a_{w}$, and at all $a_{w}$ levels and $15^{\circ} \mathrm{C}$. However, some DON may be produced at $0.97 a_{w}$ and $15^{\circ} \mathrm{C}$. The optimum for DON production was observed at $30^{\circ} \mathrm{C}$ while for ZEA at $25^{\circ} \mathrm{C}$ at the wettest conditions. The total combined FUMs (sum of fumonisins $B_{1}$ and $B_{2}$ ) production was higher at $0.97 a_{w}$ and $30^{\circ} \mathrm{C}$ while at reduced $a_{w}$ levels the optimum appeared to be at $25^{\circ} \mathrm{C}$. No FUMs were produced at $15^{\circ} \mathrm{C}$ in any of the samples over the time scale of this experiment, while under the driest conditions tested $\left(0.91 a_{w}\right)$ some FUMs were produced at $25^{\circ} \mathrm{C}$. Data were also collected on the individual FUMs. Interestingly, the ratio of fumonisin $B_{1} /$ fumonisin $B_{2}$ was found to be between 4 and 8 and to increase with increasing temperature and $a_{w}$ (data not shown).

For DON and ZEA, the Kruskal-Wallis test by ranks was used for the analysis of the raw data. For DON the effect of $a_{w}$ was highly significant $(p=0.000)$, while the effect of temperature was not significant $(p=0.071)$. For ZEA the effect of $a_{w}$ was also highly significant $(p=0.001)$, while the effect of temperature was significant $(p=0.043)$. The Kruskal-Wallis test was also highly significant for the effect of $a_{w}$ on the total FUMs $(p=0.000)$, while the effect of temperature was found significant $(p=0.042)$. 
298

299

300

301

302

303

304

305

306

307

308

309

310

311

312

313

314

315

316

317

318

319

\section{Development of models of DML and toxin production with regard to storage} conditions

The following equation was fitted for the effect of $a_{w}$ and temperature as well as their interaction $\left(a_{w} \times T\right)$ on the DMLs and DON production in wheat colonised by $F$. graminearum:

$D M L$ wheat $=b_{\mathbf{0}}+b_{\mathbf{1}} a_{w}+b_{\mathbf{2}} T+b_{\mathbf{3}} a_{w}^{\mathbf{2}}+b_{\mathbf{5}} a_{w} T$ (eq. 1)

The quadratic effect of temperature $\left(\mathrm{T}^{2}\right)$ was not significant in either DMLs or DON production in wheat. The values for the coefficients $b_{0}-b_{5}$ as well as the statistical significance of the factors in each case are presented in Table 1.

For maize, the residuals for DMLs were not normally distributed and therefore the data were logarithmically transformed before regression. Only the effects of $a_{w}{ }^{2}$, $\mathrm{T}^{2}$ and $\mathrm{a}_{\mathrm{w}} \times \mathrm{T}$ were significant on logDMLs (eq. 2).

$\log D M L$ maize $=b_{0}+b_{\mathbf{3}} a_{w}^{\mathbf{2}}+b_{\mathbf{4}} T^{\mathbf{2}}+b_{\mathbf{5}} a_{w} T$ (eq. 2)

The values for the coefficients as well as the statistical significance of the factors in each case are presented in Table 1.

For the sum of fumonisins only the effects of $T, T^{2}$ and $a_{w} \times T$ were found to be significant on logFUMs (eq. 3) and the coefficients and the statistical significance of each of the factors are presented in Table 1.

$$
\log \text { FUMS }=b_{\mathbf{2}} T+b_{\mathbf{4}} T^{\mathbf{2}}+b_{\mathbf{5}} a_{w} T \text { (eq. 3) }
$$

Due to the pattern of ZEA production which increased up to $25^{\circ} \mathrm{C}$ and sharply decreased at $30^{\circ} \mathrm{C}$, it has been considered more relevant to only include the data up to $25^{\circ} \mathrm{C}$ for input in the regression. A similar approach has been previously used by 
320 Marín et al. (2008) in order to model toxin production by Aspergillus carbonarius in

321 pistachio nuts. Using this approach, all factors were significant on ZEA except of $\mathrm{T}^{2}$

322 and an equation similar to eq.1 could be used for the effect of storage factors on

323 ZEA production in stored wheat, for temperatures up to $25^{\circ} \mathrm{C}$. The coefficients for

324 each factor and the statistical significance are provided in Table 1.

325 Contour maps were constructed for the DMLs and DON in wheat and log DMLs 326 and logFUMs in maize with regard to the storage conditions, based on the above 327 equations (Figure 4). From these maps the $a_{w} \times$ temperature regions where DMLs 328 and toxin production are optimum and those where these are marginal can be clearly 329 identified.

\section{Correlation between dry matter losses and toxin production}

331 Figure 5 shows a scatter plot of the DML and DON production data obtained in 332 wheat under different combinations of storage conditions. There was a highly 333 significant positive correlation between DMLs and DON (Spearman Rank Order 334 Correlations test: $R=0.9572, p=0.0000)$. The solid straight line denotes the $E U$ limit 335 established for DON in wheat for human consumption $\left(1750 \mu \mathrm{g} \mathrm{kg}^{-1}\right)$. More than $80 \%$ 336 of the samples with $>1 \%$ DMLs had DON levels exceeding the EU limits for this toxin 337 in wheat. A significant positive correlation $(R=0.8371, p=0.0000)$ was also obtained 338 between DMLs caused in maize and FUMs (total) (Figure 6) and in this case the 339 solid straight line denotes the EU limits for the sum of fumonisins in feed maize(4000 $340 \mu \mathrm{kg}^{-1}$ ). In this case more than $75 \%$ of the maize samples with $>0.9 \%$ DMLs had 341 total fumonisin levels above the EU limits, however as opposed to the wheat 342 samples, one sample contained total fumonisin levels above the EU limits with as 343 little as $0.66 \%$ DMLs. 
$344 \quad$ Plotting the data for ZEA against DMLs in a similar way also gave a statistically 345 highly significant positive correlation $(R=0.5536, p=0.0005)$ (data not shown). A 346 much higher significant correlation $(R=0.9160, p=0.0000)$ between the two variables 347 could be obtained if only the data between 15 and $25^{\circ} \mathrm{C}$ were considered (Figure 7). 348 Due to the pattern of ZEA production under different combinations of storage 349 conditions, just above $70 \%$ of the samples with DMLs $>1 \%$ exceeded the legislative 350 limits for this toxin in the wheat samples.

\section{Discussion}

352 In this study, growth of $F$. graminearum and $F$. verticillioides on wheat for human 353 consumption and feed maize respectively was determined by the amount of $\mathrm{CO}_{2}$ 354 produced during storage. Using this technique we have previously determined the 355 growth boundaries of $F$. langsethiae on oat grain for the first time (Mylona and 356 Magan, 2011).

Growth optima for F. graminearum were found in this study to be similar to those reported in the literature, determined either visually by semi-quantitative methods or by fungal colony diameter measurements (Cuero et al., 1987; Hope et al., 2005). As opposed to previous studies where $0.92 \mathrm{a}_{\mathrm{w}}$ was found marginal for the growth of $F$. verticillioides by either colony measurements or scanning electron microscopy (SEM) (Marín et al., 1995; Torres et al., 2003; Samapundo et al., 2005), we observed growth even at $0.91 \mathrm{a}_{\mathrm{w}}$ at $>20^{\circ} \mathrm{C}$. Optima were at $30^{\circ} \mathrm{C}$ and $0.97 \mathrm{a}_{\mathrm{w}}$ similar to those reported in previous studies. Overall, the results presented in this work are in good agreement with published data, suggesting that fungal growth boundaries on grains may be accurately estimated by the amount of $\mathrm{CO}_{2}$ produced during storage. It is 
367 believed that in situ this method may be more accurate for monitoring potential for spoilage in cereals and improve the management of the post-harvest storage phase.

Using the $\mathrm{CO}_{2}$ data we calculated the dry matter losses (DMLs) caused in wheat and maize during fungal colonisation by $F$. graminearum and $F$. verticillioides respectively and developed model relationships and contour maps to visualise the

372 effect of storage conditions on the losses. Similar maps were also constructed for the effect of storage conditions on mycotoxin production. These maps may be very useful in identifying high- and low-risk conditions for mycotoxin contamination in stored wheat and maize, since $a_{w}$ or temperature stress applied during control strategies could stimulate the production of other toxins instead. For example, storing grain at $<15^{\circ} \mathrm{C}$ could reduce the risk of DON or FUMs contamination, but would not be very efficient against ochratoxin A formation by Penicillium species, which has been shown to occur in as low as $10^{\circ} \mathrm{C}$ (Lindblad et al. 2004). On the other hand, an increase in storage temperature of wheat to $30^{\circ} \mathrm{C}$ would dramatically increase the chances of DON contamination, while causing a reduced presence of ZEA. This kind of switches in the major mycotoxin contamination in food/feed may be important when considering and developing predictions of the effects of an increase in the average global temperature due to climate change (Magan et al, 2011). However, similar information should also be obtained for other metabolites produced by the same species which may be optimally produced under different combinations of storage conditions.

We have obtained some highly significant correlations between DMLs and toxin production in stored wheat and maize. From the correlations obtained in this study between DMLs and DON in wheat and DMLs and total FUMs in feed maize, it is suggested than in both cases EU limits are likely to be exceeded when very small 
392 DMLs are reached $(0.9-1 \%)$. This means that the tolerances are very low and this 393 type of information could be used practically for improving management of grain in 394 the post-harvest component of the food chain. Thus continuous monitoring of $\mathrm{CO}_{2}$ 395 concentration in silos and the determination of DMLs as a possible indicator of the 396 level of contamination of stored grain with mycotoxins could be beneficial. This could minimise the chances of grain lots exceeding the legal limits for the toxins of counts of mycotoxigenic fungi or ergosterol measurements (Lund and Frisvad, 2003; Lindblad et al., 2004;Yong and Cousin, 2001). Previous studies in wheat which examined the effect of Penicillium verrucosum colonisation, ochratoxin A (OTA) contamination and environmental conditions suggested that for this species the 405 presence of much lower populations (Log 3 CFUs $g^{-1}$ ) would result in OTA 406 contamination above the EU legislative limits (Lund and Frisvad, 2003; Lindblad et 407 al., 2004). The serial dilution method used is more appropriate for highly sporulating 408 fungi such as Penicillium and Aspergillus species while this technique is less 409 appropriate for Fusarium species which may be underestimated (Thrane, 1996). 410 Despite this, F. verticillioides populations isolated from the maize samples in this 411 study after 10 days storage under conducive conditions were higher than log 7 CFUs 412 per gram grain in all the samples where fumonisin levels were above the EU limits 413 (data not shown). We also observed a significant correlation between the CFU 414 populations of $F$. verticillioides and $\log \mathrm{DML}(\mathrm{R}=0.69, \mathrm{p}<0.001)$, while the correlation 415 between CFUs and the sum of FUMs $(R=0.45)$ was significant at $p<0.05$ level. This 416 suggests that where microconidia are produced, perhaps CFUs could be used as a 
417 contamination risk index in stored maize for long term monitoring of a stored batch.

418 However, $\mathrm{CO}_{2}$ monitoring as a non-invasive technique can be observed in real time 419 which may be more appropriate than traditional mycological methods.

420 Ecological studies often focus on the determination of single toxins produced by 421 the fungal species of concern, usually the ones controlled by legislation, while 422 several metabolites are usually produced on naturally contaminated grain. 423 Consequently very little is known about the effect of storage conditions on 424 "secondary" toxins or the full range of metabolites that may be produced by single 425 species. In this study we determined fumonisin $B_{1}$ and $B_{2}$ production in maize and 426 observed that at intermediate $a_{w}$ levels the optimum production shifted at lower 427 temperatures. This has also been observed previously with $F$. verticillioides and $F$. 428 proliferatum (Marín et al., 1999). In our study fumonisins $B_{3}$ and $B_{4}$ were also 429 detected in all the maize samples. While fumonisin $B_{4}$ was present in smaller 430 amounts, fumonisin $B_{3}$ was present at levels similar to that of fumonisin $B_{2}$ and 431 occasionally even higher - especially at $30^{\circ} \mathrm{C}$ and 0.955 and $0.97 \mathrm{a}_{\mathrm{w}}$ (data not 432 shown). This may be of particular importance under temperature and water stress 433 shifts which are important in predicting the impacts of climate change scenarios on 434 mycotoxins in staple food commodities. Thus shifts to fumonisin $B_{3}$ instead of $B_{1}$ and $435 \quad B_{2}$ which is the focus of control strategies at present could become important.

436 In conclusion, this study has shown that $\mathrm{CO}_{2}$ data under different interacting 437 environmental conditions can be used to quantify the DMLs which can be caused by 438 mycotoxigenic fungi in both wheat and maize. It is also possible to relate the DMLs 439 to the EU legislative limits for DON and FUMs in wheat and maize respectively. This 440 suggests that for these toxins the relative threshold tolerances for minimising the 441 chances of exceeding the EU legislative limits are small. We have also shown that it 
442 may be possible to use $\mathrm{CO}_{2}$ production in stored cereals to improve management of 443 grain post-harvest as part of a food chain prevention strategy.

444

445 Acknowledgements

446 We are grateful to the EU for funding this work via the FP7 MYCORED Project 447 (Grant Agreement No. 222690). We would also wish to thank the MYCORED 448 partners in the Department of Agrobiotechnology of the University of Natural 449 Resources and Life Sciences, IFA-Tulln, Austria for performing the toxin analysis of 450 the samples.

451

\section{References}

453 Casado MR, Parsons DJ, Magan N, Weightman RM, Battilani P, Pietri A. 2010. A 454 short geostatistical study of the three dimensional spatial structure of fumonisins in 455 stored maize. World Mycotoxin Journal 3(1): 95-103.

456 Cleveland TE, Dowd PF, Desjardins AE, Bhatnagar D, Cotty PJ. 2003. United States 457 Department of Agriculture - Agricultural Research Service research on pre-harvest 458 prevention of mycotoxins and mycotoxigenic fungi in US crops. Pest Management 459 Science 59: 629-642.

460 Cuero RG, Smith JE, Lacey J. 1987. Interaction of water activity, temperature and 461 substrate on mycotoxin production by Aspergillus flavus, Penicillium viridicatum and 462 Fusarium graminearum in irradiated grains. Transactions of the British Mycological 463 Society 89 (2): 221-226. 
464 Etcheverry MG, Scandolara A, Nesci A, Vilas Boas Ribeiro MS, Pereira P, Battilani

465 P. 2009. Biological interactions to select biocontrol agents against toxigenic strains

466 of Aspergillus flavus and Fusarium verticillioides from maize. Mycopathologia 167:

$467 \quad 287-295$.

468 European Commission, 2005-2009. The Rapid Alert System for Food and Feed, 469 RASFF) Annual Reports 2005-2009.

470 European Commission, 2006a.Commission Regulation (EC) No 1881/2006 of 19

471 December 2006 setting maximum levels for certain contaminants in foodstuffs.

472 Official Journal of the European Union, L 364, 5-24.

473 European Commission, 2006b.Commission Regulation (EC) No 401/2006 of 23

474 February 2006 laying down the methods of sampling and analysis for the official 475 control of the levels of mycotoxins in foodstuffs. Official Journal of the European 476 Union, L 70, 12-34.

477 FAO, 2009. FAOSTAT database. Food and Agricultural commodities production. 478 http://faostat.fao.org/site/339/default.aspx

479 Fleurat-Lessard F. 2002. Qualitative reasoning and integrated management of the 480 quality of stored grain: a promising new approach. Journal of Stored Product 481 Research 38: 191-218.

482 Hope R, Aldred D, Magan N. 2005. Comparison of environmental profiles for growth 483 and deoxynivalenol production by Fusarium culmurum and Fusarium graminearum 484 on wheat grain. Letters in Applied Microbiology 40: 295-300. 
485 Lacey J, Hamer A, Magan N. 1994. Respiration and losses in stored wheat under 486 different environmental conditions. Proceedings of the $6^{\text {th }}$ International Working 487 Conference on Stored Product Protection..

488 Lindblad M, Johnsson P, Jonsson N, Lindqvist R, Olsen M. 2004. Predicting non489 compliant levels of ochratoxin A in cereal grain from Penicillium verrucosum counts. 490 Journal of Applied Microbiology 97: 609-616.

491 Lund F, Frisvad JC. 2003. Penicillium verrucosum in wheat and barley indicates 492 presence of ochratoxin A. Journal of Applied Microbiology 95: 1117-1123.

493 Magan N, Aldred D. 2007. Post-harvest control strategies: minimising mycotoxins in 494 the food chain. International Journal of Food Microbiology 119: 131-139.

495 Magan N, Aldred D, Mylona K, Lambert RJW. 2010. Review: Limiting mycotoxins in 496 stored wheat. Food Additives and Contaminants 27: 644-650.

497 Magan N, Medina A, Aldred D. 2011. Review: Possible climate-change effects on 498 mycotoxin contamination of food crops pre- and post-harvest. Plant Pathology 60: $499 \quad 150-163$.

500 Marín P, Jurado M, Magan N, Vázquez C, González-Jaén MT. 2009. Effect of solute 501 stress and temperature on growth rate and TRI5 gene expression using real time 502 RT-PCR in Fusarium graminearum from Spanish wheat. International Journal of 503 Food Microbiology 140: 169-174.

504 Marín S, Sanchis V, Magan N. 1995. Water activity, temperature and pH effects on 505 growth of Fusarium moniliforme and F. proliferatum isolates from maize. Canadian 506 Journal of Microbiology 41: 1063-1070. 
507 Marín S, Homedes V, Sanchis V, Ramos AJ, Magan N. 1999. Impact of Fusarium

508 moniliforme and $F$. proliferatum colonisation of maize on calorific losses and

509 fumonisin production under different environmental conditions. Journal of Stored

510 Products Research 35: 15-26.

511 Marín S, Hodžić I, Ramos AJ, Sanchis V. 2008. Predicting the growth/no-growth

512 boundary and ochratoxin A production by Aspergillus carbonarius in pistachio nuts.

513 Food Microbiology 25: 683-689.

514 Miller JD. 2008. Review: Mycotoxins in small grains and maize: Old problems, new 515 challenges. Food Additives and Contaminants 25: 219-230.

516 Mylona K, Magan N. 2011. Fusarium langsethiae: storage environment influences

517 dry matter losses and T2 and HT-2 toxin contamination of oats. Journal of Stored

518 Products Research 47: 321-327.

519 Nithya U, Chelladurai V, Jayas DS, White NDG. 2011. Safe storage guidelines for 520 durum wheat. Journal of Stored Products Research. doi:10.1016/j.jspr.2011.05.005.

521 Pasquali M, Giraud F, Brochot C, Cocco E, Hoffmann L, Bohn T. 2010. Genetic 522 Fusarium chemotyping as a useful tool for predicting nivalenol contamination in 523 winter wheat. International Journal of Food Microbiology 137: 246-253.

524 Samapundo S, Devliehgere F, De Meulenaer B, Debevere J. 2005. Effect of water 525 activity and temperature on growth and the relationship between fumonisin 526 production and the radial growth of Fusarium verticillioides and Fusarium 527 proliferatum on corn. Journal of Food Protection 68(5): 1054-1059. 
528 Sanchis, V., Magan, N. 2004. Environmental conditions affecting mycotoxins.

529 Chapter 8 In Mycotoxins in food: detection and control. Edts, N. Magan and M. Olsen.

530 Woodhead Publishing Ltd, Cambridge, U.K. pp. 174-189.

531 Scientific Committee on Food (SCF), 2002. Opinion of the Scientific Committee on

532 Food on Fusarium toxins. Part 6: Group evaluation of T-2 toxin, HT-2 toxin, nivalenol

533 and deoxynivalenol.

534 Seitz LM, Sauer DB, Mohr HE,Aldis DF. 1982. Fungal growth and dry matter loss 535 during bin storage of high moisture corn. Cereal Chemistry 59: 9-14.

536 Sulyok M, Berthiller F, Krska R, Schuhmacher R. 2006. Development and validation 537 of a liquid chromatography/tandem mass spectrometric method for the determination 538 of 39 mycotoxins in wheat and maize. Rapid Communications in Mass Spectrometry 539 20: 2649-2659.

540 Thrane U. 1996. Comparison of three selective media for detecting Fusarium 541 species in foods: a collaborative study. International Journal of Food Microbiology 542 29: 149-156.

543 Torres MR, Ramos AJ, Soler J, Sanchis V, Marín S. 2003. SEM study of water 544 activity and temperature effects on the initial growth of Aspergillus ochraceous, 545 Alternaria alternata and Fusarium verticillioides on maize grain. International Journal 546 of Food Microbiology 81: 185-193.

547 Vishwanath V, Sulyok M, Labuda R, Bicker W, Krska R. 2009. Simultaneous 548 determination of 186 fungal and bacterial metabolites in indoor matrices by liquid 549 chromatography/ tandem mass spectrometry. Annals of Bioanalytical Chemistry 395: $550 \quad 1355-1372$. 
551 Wagacha JM, Muthomi JW. 2008. Review: Mycotoxin problem in Africa: Current

552 status, implications to food safety and health and possible management strategies.

553 International Journal of Food Microbiology 124: 1-12.

554 White NDG, Sinha RN, Muir WE. 1982a. Intergranular carbon dioxide as an indicator

555 of biological activity associated with the spoilage of stored wheat. Canadian 556 Agricultural Engineering 24: 35-42.

557 White NDG, Sinha RN, Muir WE.1982b. Intergranular carbon dioxide as an indicator

558 of deterioration in stored rapeseed. Canadian Agricultural Engineering 24: 43-49.

559 Yong RK, Cousin MA. 2001. Detection of moulds producing aflatoxins in maize and 560 peanuts by an immunoassay. International Journal of Food Microbiology 65: 27-38. 
562 Table 1.Values of coefficients $b_{0}-b_{5}$ and statistical significance of the relevant factors 563 in the model equation for DMLs and for toxin production as determined by forward 564 stepwise regression. Highly significant p-values are shown in bold.

\begin{tabular}{|c|c|c|c|c|c|c|c|c|c|c|}
\hline & \multicolumn{2}{|c|}{$\begin{array}{l}\text { DMLs } \\
\text { wheat }\end{array}$} & \multicolumn{2}{|c|}{$\begin{array}{c}\text { logDMLs } \\
\text { maize }\end{array}$} & \multicolumn{2}{|c|}{ DON } & \multicolumn{2}{|c|}{$\begin{array}{l}\text { ZEA (up } \\
\text { to } 25^{\circ} \mathrm{C} \text { ) }\end{array}$} & \multicolumn{2}{|c|}{ logFUMs } \\
\hline & b & $\begin{array}{l}\frac{0}{2} \\
\frac{1}{10} \\
\frac{1}{2}\end{array}$ & b & 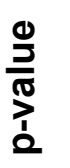 & b & $\begin{array}{l}\frac{0}{2} \\
\frac{1}{2} \\
\text { อ }\end{array}$ & b & $\begin{array}{l}\frac{0}{2} \\
\frac{1}{2} \\
\text { ¿̇ }\end{array}$ & b & $\begin{array}{l}\frac{0}{2} \\
\frac{2}{10} \\
\frac{1}{2}\end{array}$ \\
\hline $\begin{array}{c}\text { Intercept } \\
\left(b_{0}\right)\end{array}$ & $\begin{array}{l}\text { Lे } \\
\infty \\
0 \\
0 \\
0\end{array}$ & $\begin{array}{l}\text { 오 } \\
\text { ㅇ }\end{array}$ & $\begin{array}{l}\infty \\
0 \\
1\end{array}$ & $\begin{array}{l}\text { 옹 } \\
\text { ㅇ }\end{array}$ & 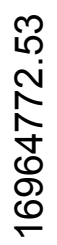 & $\begin{array}{l}\text { 옹 } \\
\text { ㅇ }\end{array}$ & 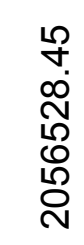 & $\begin{array}{l}\text { 용 } \\
\text { ㅇ. }\end{array}$ & $\begin{array}{l}\hat{\bigcup} \\
\stackrel{\gamma}{1}\end{array}$ & $\begin{array}{l}\text { Y } \\
\text { O }\end{array}$ \\
\hline$a_{w}\left(b_{1}\right)$ & $\begin{array}{l}\frac{n}{0} \\
\frac{0}{6} \\
\frac{6}{1}\end{array}$ & $\begin{array}{l}\text { 응 } \\
\text { ' }\end{array}$ & 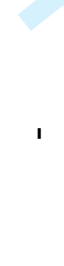 & ' & 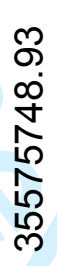 & $\begin{array}{l}\text { 응 } \\
\text { ' }\end{array}$ & 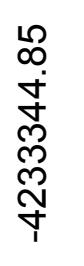 & $\begin{array}{l}8 \\
8 \\
\circ\end{array}$ & I & ' \\
\hline $\mathbf{T}\left(\mathbf{b}_{2}\right)$ & $\begin{array}{l}\text { ठे } \\
\text { Pें }\end{array}$ & $\begin{array}{l}\text { 용 } \\
\text { ㅇ }\end{array}$ & ' & ' & 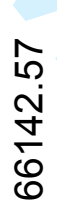 & $\begin{array}{l}\text { 옹 } \\
\text { ㅇ. }\end{array}$ & $\begin{array}{l}\stackrel{0}{+} \\
\stackrel{N}{N} \\
\underset{N}{T}\end{array}$ & $\begin{array}{l}\text { 웅 } \\
\text { ㅇ }\end{array}$ & $\begin{array}{l}\overline{0} \\
0\end{array}$ & $\begin{array}{l}8 \\
\text { ㅇ } \\
\text { ' }\end{array}$ \\
\hline$a_{w}{ }^{2}\left(b_{3}\right)$ & $\begin{array}{l}\text { ల్ } \\
\text { న్ } \\
\infty\end{array}$ & $\begin{array}{l}\text { 용 } \\
\text { ㅇ }\end{array}$ & $\begin{array}{l}\hat{\infty} \\
\dot{\gamma}\end{array}$ & $\begin{array}{l}\text { 용 } \\
\text { ㅇ }\end{array}$ & 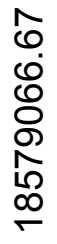 & $\begin{array}{l}\text { 응 } \\
\text { ㅇ }\end{array}$ & \begin{tabular}{l}
$\hat{m}$ \\
$\infty$ \\
\multirow{\infty}{*}{} \\
$o$ \\
\multirow{্}{*}{} \\
$\stackrel{N}{N}$
\end{tabular} & $\begin{array}{l}8 \\
\text { ㅇ } \\
0\end{array}$ & ' & ' \\
\hline $\mathrm{T}^{2}\left(\mathrm{~b}_{4}\right)$ & I & ' & 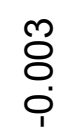 & $\begin{array}{l}\text { 용 } \\
\text { ㅇ. }\end{array}$ & ' & ' & ' & ' & $\begin{array}{l}5 \\
0\end{array}$ & $\begin{array}{l}\text { 응 } \\
\text { ㅇ }\end{array}$ \\
\hline$T^{*} a_{w}\left(b_{5}\right)$ & $\begin{array}{l}\stackrel{\sim}{\sim} \\
\forall\end{array}$ & $\begin{array}{l}\text { 용 } \\
\text { Ó }\end{array}$ & $\underset{o}{o}$ & $\begin{array}{l}\text { 용 } \\
\text { O. }\end{array}$ & 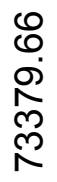 & $\begin{array}{l}\text { 용 } \\
\text { ㅇ }\end{array}$ & 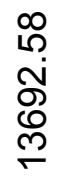 & $\begin{array}{l}8 \\
8 \\
\circ \\
0\end{array}$ & $\stackrel{\stackrel{n}{N}}{\leftarrow}$ & $\begin{array}{l}8 \\
\text { ㅇ } \\
\text { ' }\end{array}$ \\
\hline
\end{tabular}




\section{Figure legends}

567 Figure 1: Effect of $\mathrm{a}_{\mathrm{w}}$ and temperature on the cumulative $\mathrm{CO}_{2}$ production during 568 wheat colonisation by F. graminearum over time. Bars indicate the standard errors in 569 the determination of total $\mathrm{CO}_{2}$ production under each combination of storage 570 conditions.

571 Figure 2: Effect of F. graminearum and F. verticillioides colonisation of wheat and 572 maize respectively expressed as mean DMLs (\%) after 10 days of storage under 573 different $\mathrm{a}_{\mathrm{w}}$ and temperature conditions (wheat: $S E_{\max }=0.33$, maize: $S E_{\max }=1.38$ ).

574 Figure 3: Production of different mycotoxins (in $\mu \mathrm{kg}^{-1}$ ) by $F$. graminearum in wheat 575 (DON: $\mathrm{SE}_{\max }=0.59(\mathrm{E}+04)$ and $\mathrm{ZEA}: \mathrm{SE}_{\max }=0.82(\mathrm{E}+03)$ ) and $F$. verticillioides (Sum of 576 fumonisins: $\left.\mathrm{SE}_{\max }=2.33(\mathrm{E}+05)\right)$ in maize with respect to the storage conditions.

577 Figure 4: Contour maps describing the DMLs (a) and DON accumulation (b) caused 578 in irradiated wheat during the growth of $F$. graminearum and the logDMLs (c) and log 579 Fumonisin production (d) in maize during the growth of $F$. verticillioides on irradiated 580 maize under different combinations of environmental conditions.

581 Figure 5: Scatter plot of the relationship between DMLs and DON production during 582 colonisation of stored wheat by F. graminearum. The thick black line indicates the 583 EU legislative limits for DON in wheat for human consumption.

584 Figure 6: Scatter plot of the relationship between DMLs and Sum of fumonisins 585 production during colonisation of stored maize by $F$. verticillioides. The thick black 586 line indicates the EU legislative limits for the Sum of fumonisins in feed maize. 
587 Figure 7: Scatter plot of the relationship between DMLs and ZEA production between

$58815-25^{\circ} \mathrm{C}$, during colonisation of stored wheat by $F$. graminearum. The thick black line 589 indicates the EU legislative limits for ZEA in wheat for human consumption.

590 
$15^{\circ} \mathrm{C}$

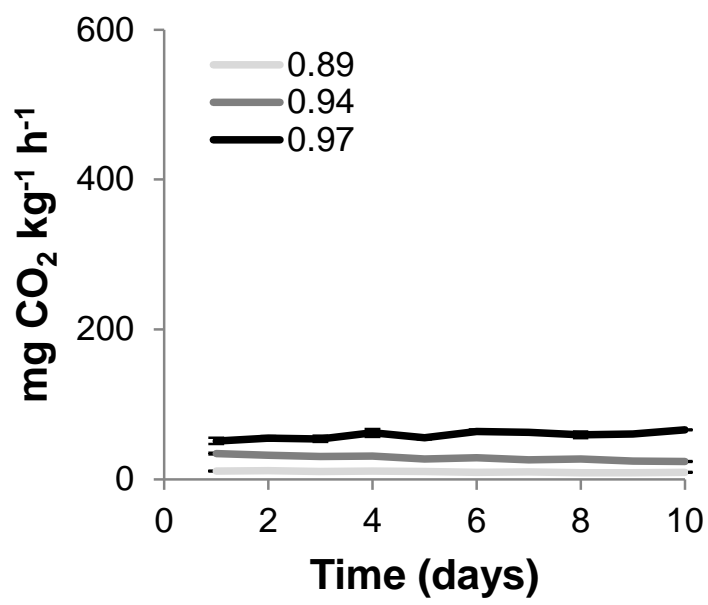

$25^{\circ} \mathrm{C}$

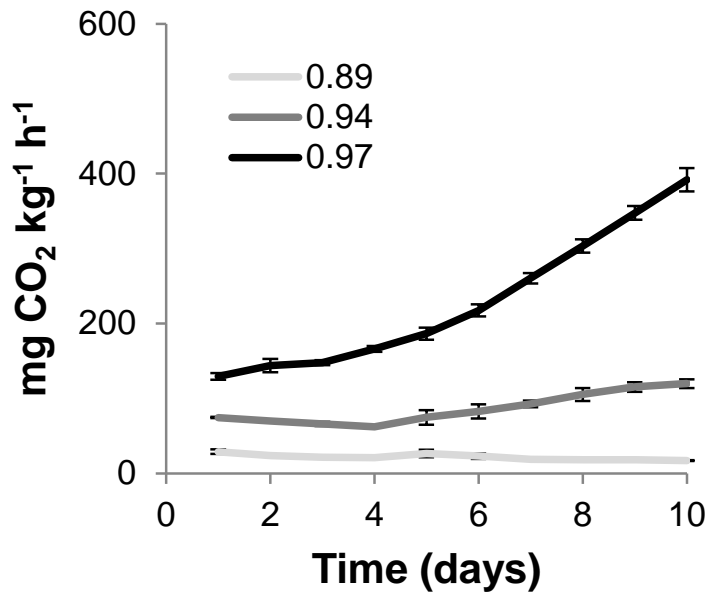

$20^{\circ} \mathrm{C}$

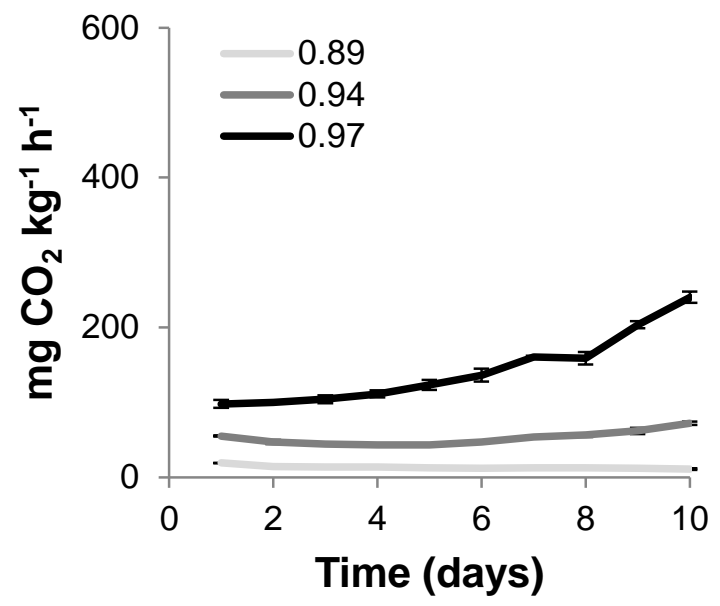

$30^{\circ} \mathrm{C}$

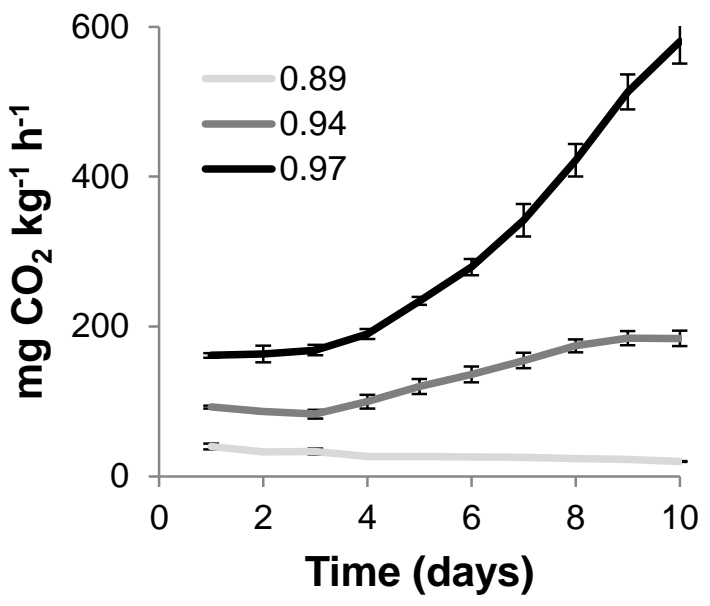

Figure 1: Mylona et al. 
a) wheat

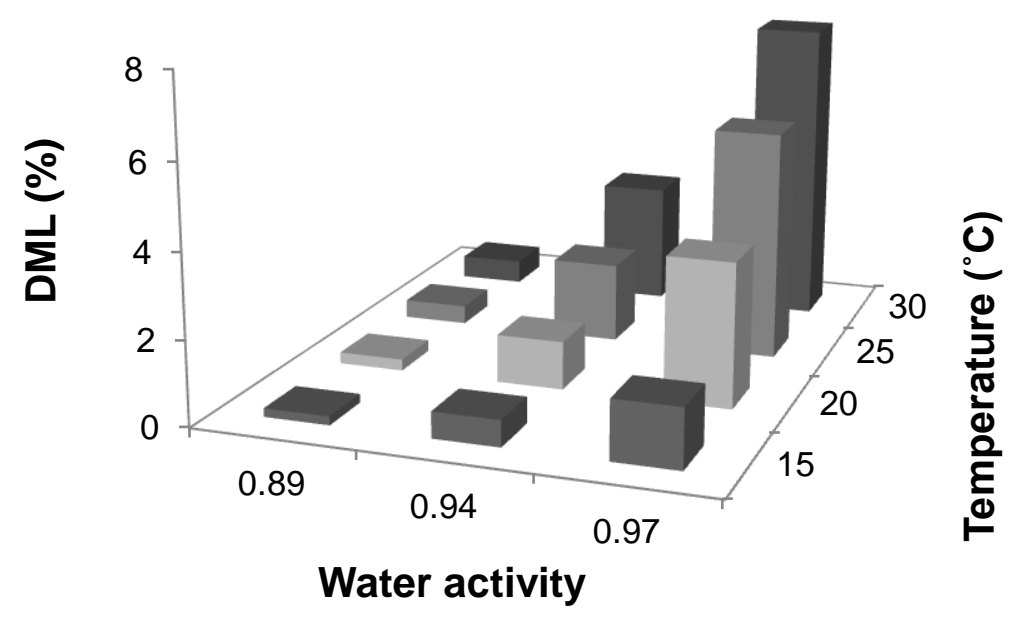

b) maize

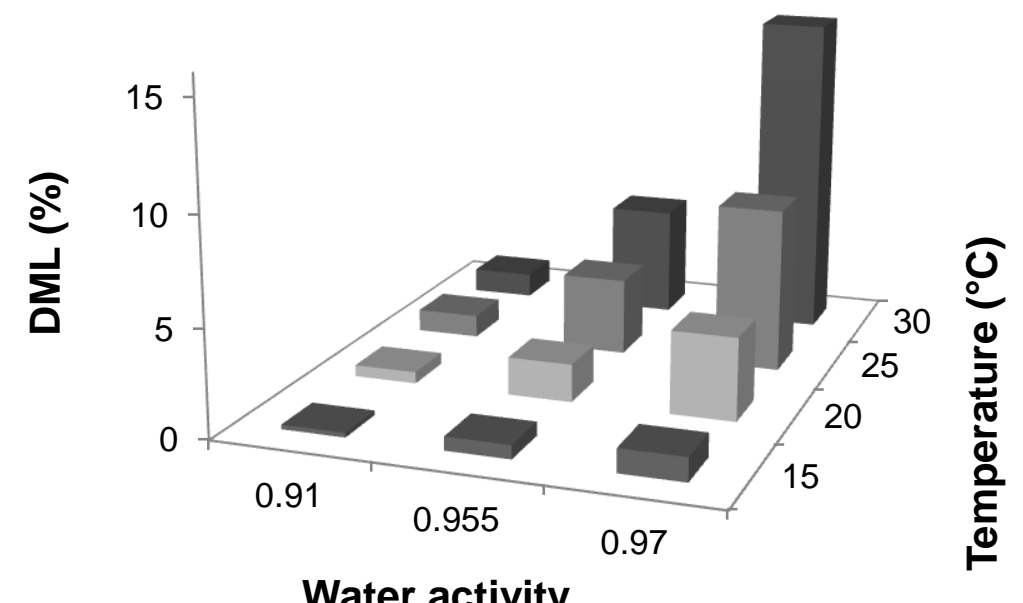

Figure 2: Mylona et al.

http://mc.manuscriptcentral.com/tfac Email: fac@tandf.co.uk 


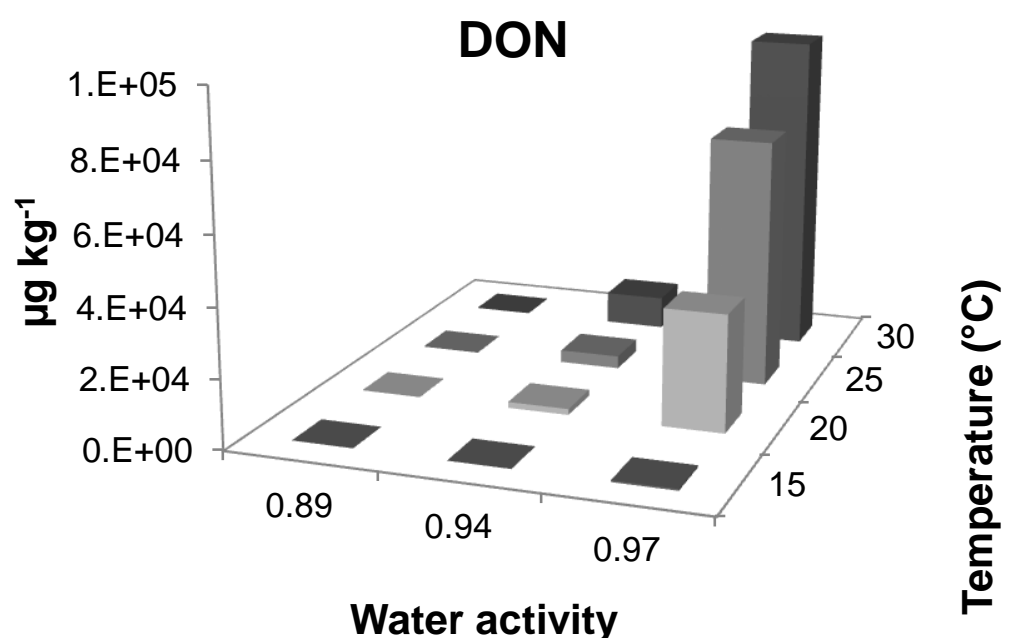

ZEA

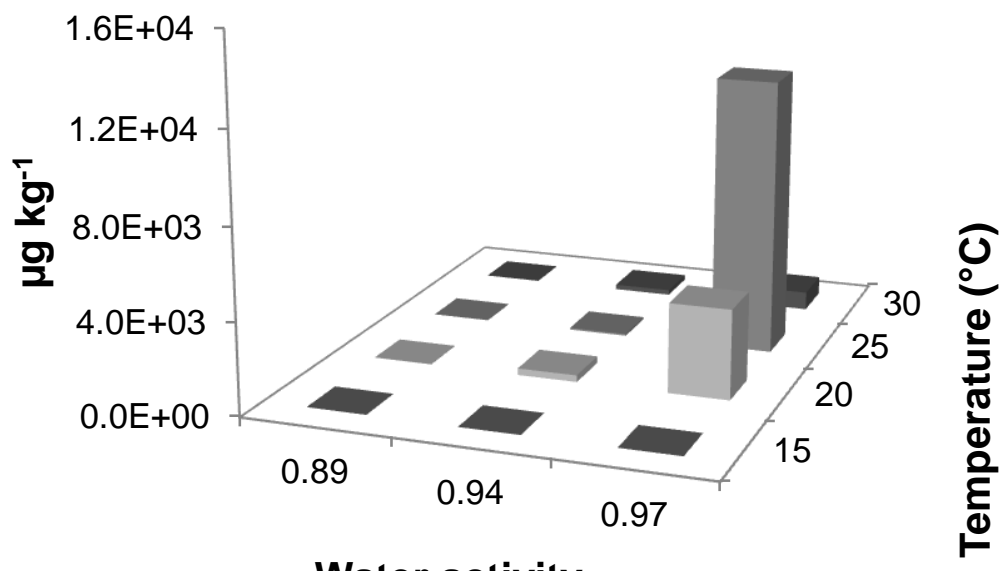

Water activity

\section{Sum of fumonisins}

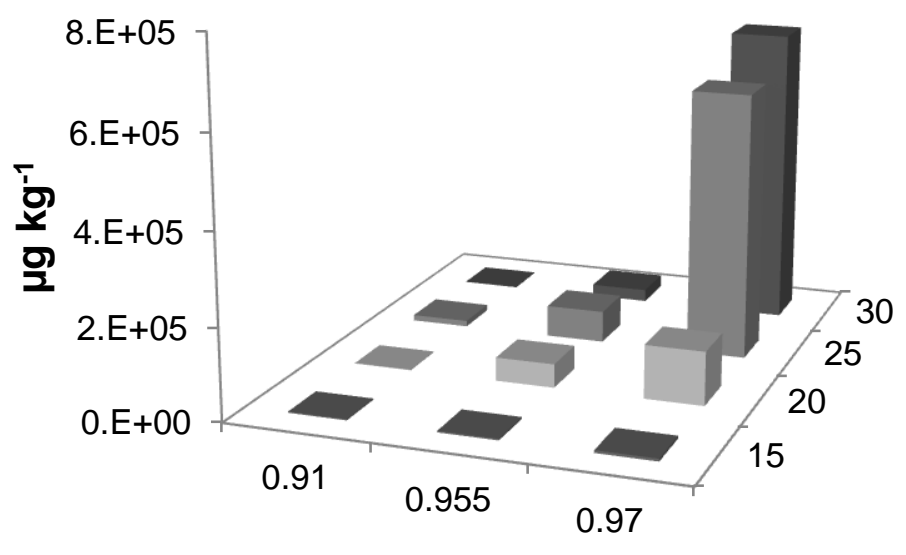

Water activity

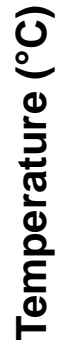

Figure 3: Mylona et al.

http://mc.manuscriptcentral.com/tfac Email: fac@tandf.co.uk 


\section{Page 33 of 35}

(a)

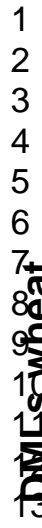

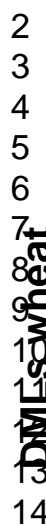

15

16

17

18

19

20

21

22

23

24

25

26

27

28

29

30

31

32

33

34

35

36

37

38

39

40

41

42

43

44

45

46

47

48

49

50

51

52

53

54

55

56

57

(c)

$-1--0.5 \square-0.5-0 \quad \square 0-0.5 \square 0.5-1$

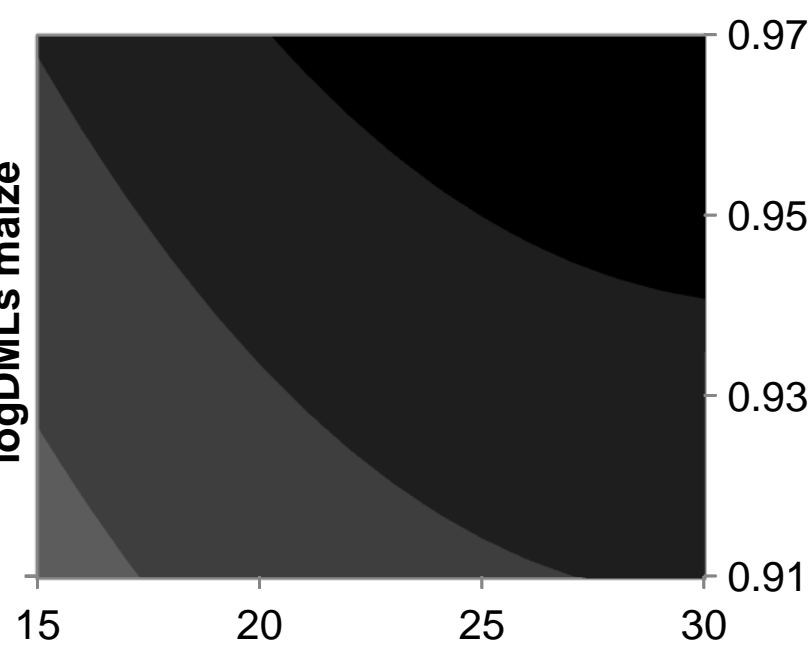

Temperature (ำ)

http://mc.manuscriptcentral.com/tfac Email: fac@tandf.co.uk

Figure 4: Mylona et al. (b)

0.97

$0-25000$

25000-50000

- $75000-100000$

- 50000-75000

0.97

d)

Ż

0.93

0.91

0.95

(d)

$2-3 \backsim 3-4 \square 4-5 \square 5-6$

Temperature ( $\left.{ }^{\circ} \mathrm{C}\right)$

0.89

30

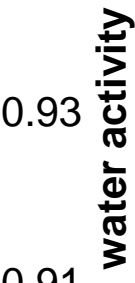

Temperature $\left({ }^{\circ} \mathrm{C}\right)$ 


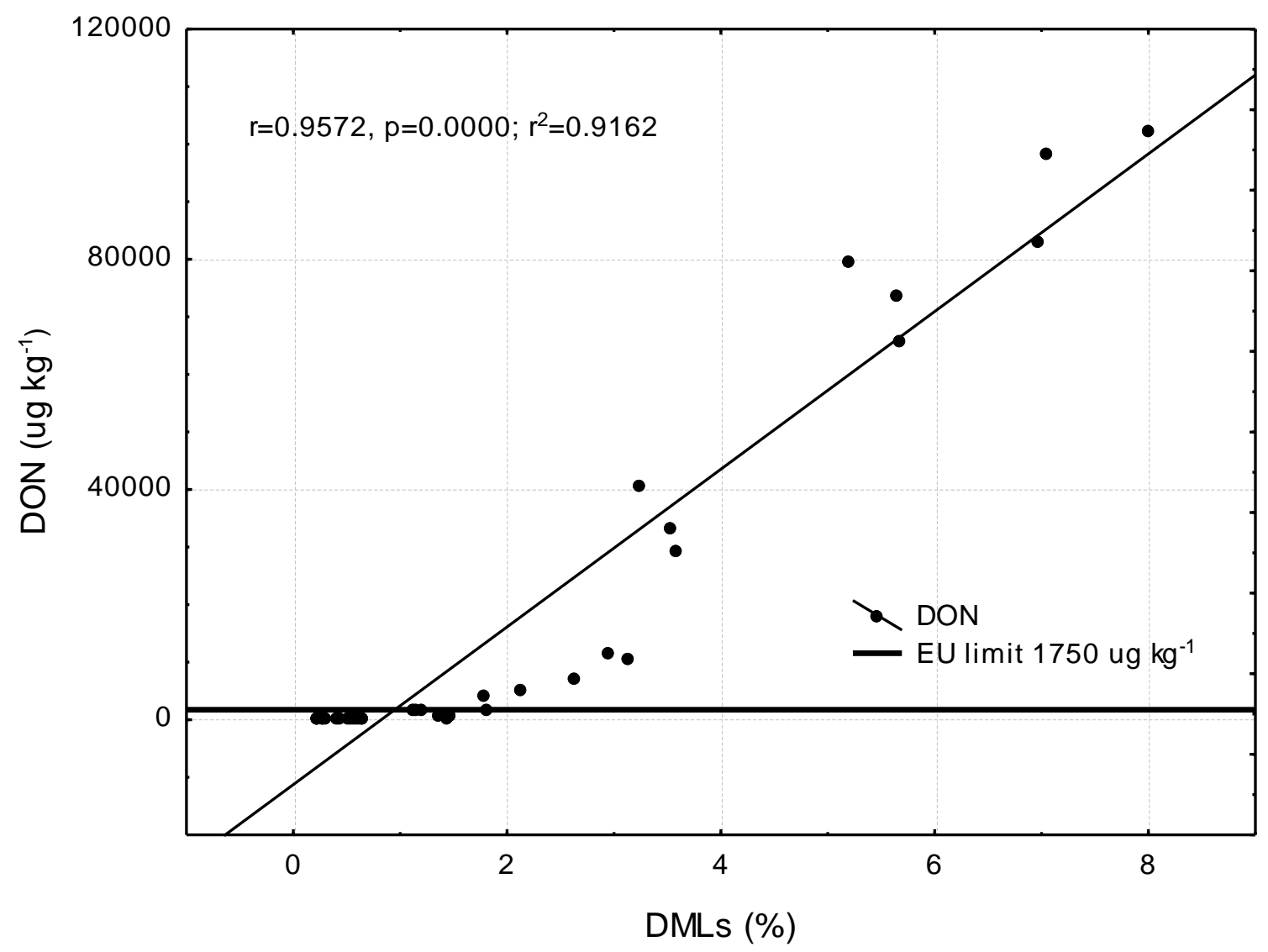

Figure 5: Mylona et al. 


\section{Page 35 of 35}

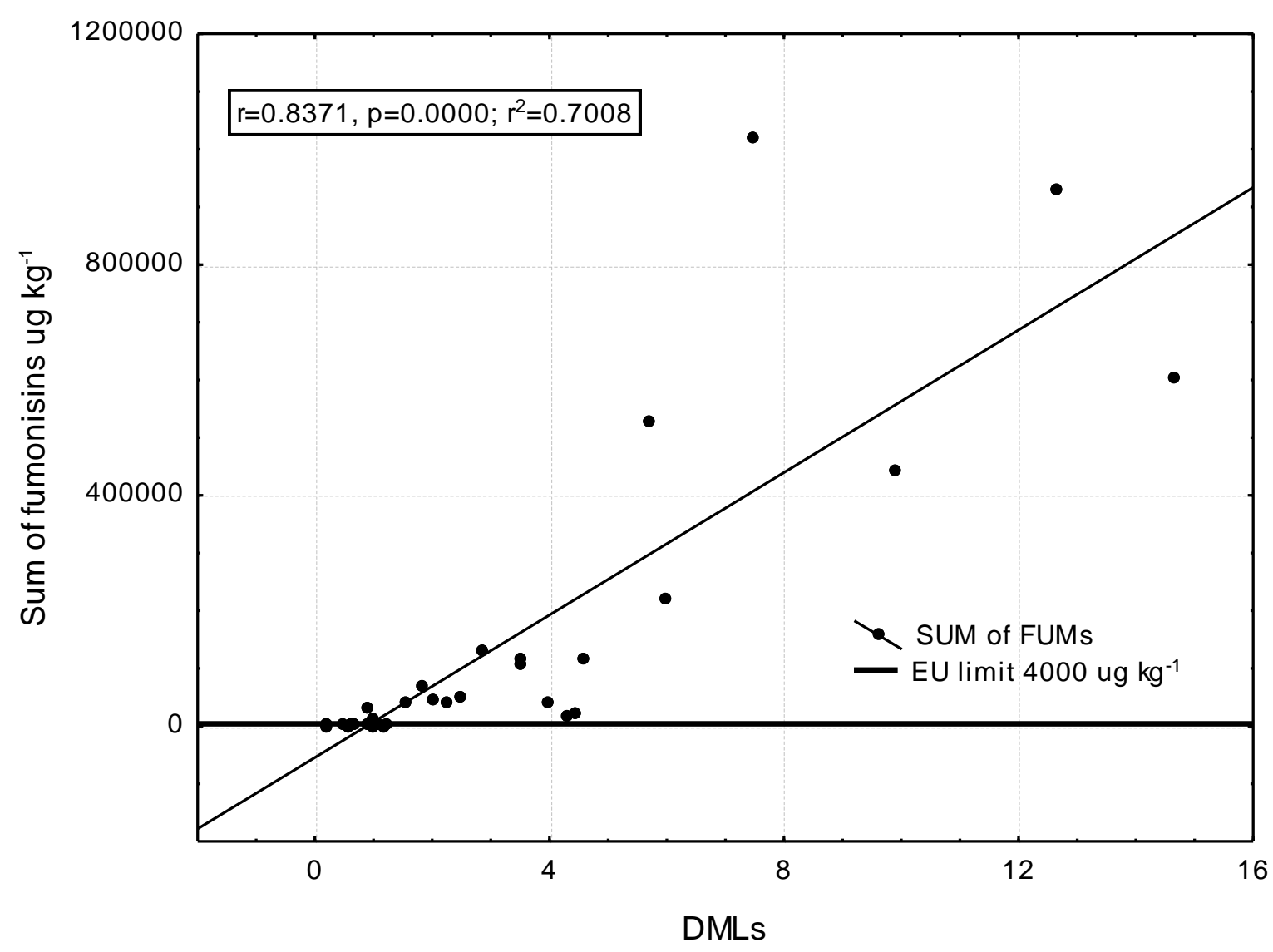

Figure 6: Mylona et al. 


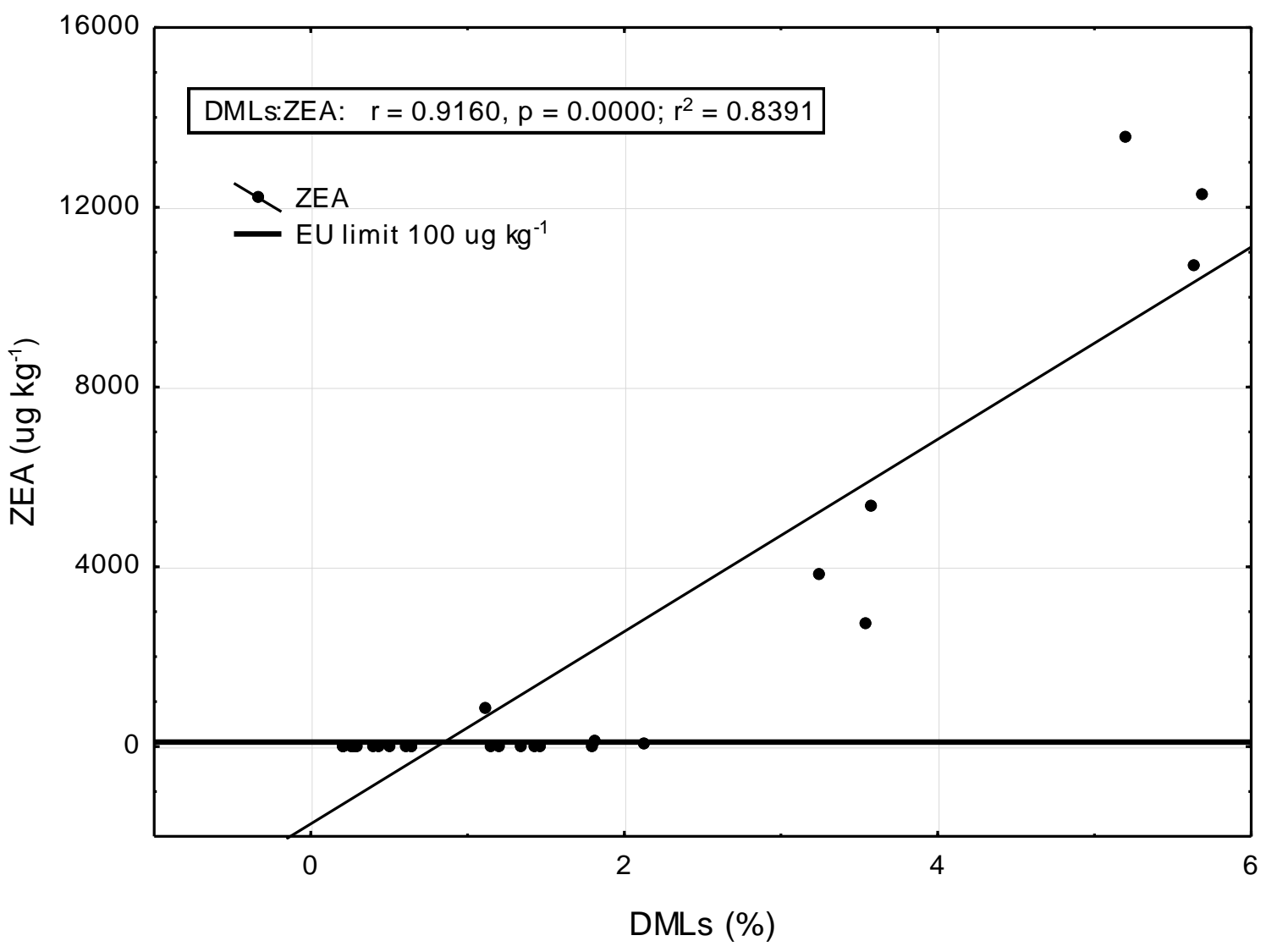

Figure 7: Mylona et al. 